\title{
ル・コルビュジエにおける「装備」概念の変容 FORMATION OF THE NOTION ON “EQUIPMENT” BY LE CORBUSIER
}

\author{
千代 章一郎* \\ Shoichiro SENDAI
}

\begin{abstract}
This paper aims to elucidate the formation of the notion on "equipment" by the Architect Le Corbusier, using his all kinds of books and his correspondences conserved in Le Corbusier Foundation. Several periods were divided for this purpose: the question of "furniture" and the birth of the notion of "equipment" before 1920's, the theorization of "equipment" in 1920's, and its transformation after 1920's. As a result, it was found that Le Corbusier's notion of "equipment" extends from the question of the interior decoration to that of the devise for the control of the natural environment.
\end{abstract}

Keywords : Le Corbusier, "Equipment", Decoration, Furniture, Control of natural environment ル・コルビュジエ,「装備」, 装飾, 家具, 自然環境制御

\section{1 はじめに}

20 世紀の建築思潮において、建築の躯体に備えられる多種多様な 家具や機械設備の問題は、建築形態論に比較すると断片的にしか論 じられていない。付帯的な機械設備を主題的に論じたジークフリー ト・ギーディオン、『機械化の文化史』（1949）は、設備の機械化が 室内装飾の変遷と密接に関連していることを指摘しているにもかか わらず、機械化される設備そのものの記述に終始しているために、 室内空間の「装飾 décoration」注1) という古典的な問題の 20 世紀的 転回は、十分には論じられていない注 2 )。「装飾」の否定という近代 建築思潮の一般的定義において、室内空間を設える様々な仕掛けに ついての言及は限定的であるが、「装飾」という用語が「家具」その ものを指すこともあるように、「装飾」そのものが空間の主題から消 滅してしまったわけではない注3)。

ところで、ル・コルビュジエ（1887～1965）は、1920 年代に住 宅における「装備 équipement」注4) について論じている。ル・コル ビュジェにおける「装備 équipement」は、「家具 meuble」の問題 を敷衍した概念であり、所謂生活の「設備 appareil」としての衛生・ 冷暖房器機の問題に収まるものではない。日常生活における室内空 間を統一的に提案するという考え方自体は、バウハウスを含め当時 の建築思潮においてそれほど新規なものではない注 5 )。たしかに、 1920 年以降、ル・コルビュジエが「装備」について主題的に論じる ことはないが、少なくとも家具などの問題について個別の建築制作 において直接的に、あるいは著作において間接的に追求し続けてい
るとすれば注 6 )、「装備」の概念が発展的に変容していると推測され る。

そこで本稿では、まず、ル・コルビュジェの 1920 年代以前の「家 具」を巡る言説から「装備」の出自を辿り (第 2 章)、次に 1920 年 代の「装備」を巡る諸概念を構造的に把握し（第 3 章）、その後の 変容の過程について系譜づける（第 4 章〜第 5 章)。

既往研究においては、1920 年代を中心としたル・コルビュジェの 「装備」における「装飾」の否定の意味を論じたもの、ル・コルビ ユジエの家具そのものの詳細な通年的形態分析、青年期のドイツ装 飾芸術研究についての分析などがある注7)。しかしながら、いずれも ル・コルビュジエの「装備」の概念を限定的に捉えているために、 その生成変化の過程については論じられていない。一方本稿では、 ル・コルビュジエの全著作から建築作品の「装備」に関する言説に 着目して抽出すると同時に、ル・コルビュジエ財団保管の関連書簡・ 手帖を網羅的に精查し、それらを用いて、「装備」の概念の生成過程 を分析する注8)

\section{2 「装備」の出自：「動かせない家具」への転節}

ル・コルビュジエは、本名のシャルル＝エドゥアール・ジャンヌ レとして、故郷のスイス、ラ・ショー＝ド=フォンでの青年期の建 築の修学において、レ・プラトニエの指導のもとにヴィラ・マティ =ドレの音楽室の改装(1906)などの改装を手がけ、ファレ邸(1907) などの新築においても、ジュラ地方に相応しい室内装飾を構想して

\footnotetext{
* 広島大学大学院工学研究科 准教授·博士 (工学) Assoc. Prof., Graduate school of Engineering, Hiroshima Univ., Dr. Eng.
} 
いる。

ラ・ショー＝ド＝フォンでの経験を通して、ジャンヌレはフラン スの動向にも注意を払うようになり、オーギュスト・ペレと交流を 持つことによって、鉄筋コンクリートによる建築作品の可能性を学 んでいる。1908 年よりしばしばパリに滞在し、そのパリを拠点にド イツやウィーンの建築運動の動向を見聞していたジャンヌレは、 1910 年にはドイツの装飾芸術の調查に赴いて報告書、『ドイツ装飾 芸術運動の研究』(1912) を作成している。報告書でジャンヌレは ドイツの工作連盟における製品の工業化やその組織体制を評価し、 新しい素材に応じた技術や形態の持つ重要性を指摘しているが、批 判もしている。1910 年に開催されたパリのサロン・ドートンヌにお けるミュンヘンの応用芸術展についての評価は、その典型である。

「しかしドイッ人に久けているのは、この報告書で最初に強調 したように、伝統や技巧があまり洗練されていないことである。 それゆえにフランス人はミュンヘンの家具に野蛮なものを指摘 する。それは耐え難きものであり、批判は辛辣なほどであった。

以上が 1912 年の展覧会の準備委員会の動機であり、全体を装飾 で覆うことを禁じ、独立した家具に衫らいを定めている。」注9) パリにおけるミュンヘンの室内装飾の展示は、アール・ヌーヴオ 一調から古典への回帰という潮流を反映し、比較的装飾を抑制した 家具による居間や寝室である。それでも、それがかえってフランス 人には装飾の素朴さと稚拙さを強調していた注10)。パリのサロン・ ドートンヌの動向は、ドイツの影響を受けなかったわけではないが、 フランス的伝統を模索して、装飾によって空間の統一感を偽装寸る ことのなく、家具は家具として「独立した家具」が求められる。ジ ヤンヌレははっきりと述べていないが、ラ・ショー＝ド=フォンの 教育改革としてはドイツ工作連盟の生産組織を評価する一方注11)、 家具そのものについては、フランスにおける世評と同様に批判的で ある注12。

一方でジャンヌレは、家具そのものだけではなく、室内空間全体 そのものについても分析し、室内空間としての視覚的統一性という 観点から、ドイツの装飾芸術を評価してもいる注13)。

「パリの人々は美的感覚については懐疑的である。ここで明ら かなことは二つの人種の適合不可能性である。眼に入ってくる ものはドイツ人の魂の表現である。しかしパリの人々は、まっ たく評価しないにしても、抗しがたい調和によって印象づけら れる。帷、生地、家具、絨毯、吊照明、食器、置物、すべてが 関係、比例、適合性、統一性を実現したいという願望から生ま れている。卓越して調和的であった。」注14)

こうしてジャンヌレは、1912 年にはラ・ロックルのヴィラ・ファ ーヴルとラ・ショー＝ド＝フォンの（両親のための） ヴィラ・ジャ ンヌレの建設、また、シュウォブ家、ルヴァイアン家、ディティス ハイム家の内装改修を手がけ、地方的な様式を単純化した室内空間 としている注15)。こうしたなかで、ジャンヌレはペレに対して、な かでもフランシス・ジュルダンの家具について、自らの考えを明ら かにするようになる。

「ジュルダンの素描には大いに困惑させられます。十年前にド イッでつくられた家具ですが、今や年代物です。今ではもっと 別の考え方ができると思います。壁に備え付けられた家具は建
物のように動かせない代物です。はたして何年もそんな生活が できるのでしょうか。」注16)

1913 年に発表されたジュルダンの家具注17) は、ロースの影響を 受けて棚、椅子、机、寝室などが同一素材の木製の幾何学的形態で 統一され、家具と壁との一体化を志向した「建築の延長」としての 家具である注18)。しかしジャンヌレによれば、それはアール・ヌー ヴォーの「建築のような家具immeubles-meubles」と変わりがない 注19）。ジャンヌレは、ラ・ショー＝ド＝フォンの富豪層の住宅のた めにルイ16世紀様式からディレクトワール様式などの歴史的装飾 家具を参照しているように注20)、建築物との構想に付随するものと して家具を位置づけて、自ら図面を引くことはない。ジャンヌレは 1910年のドイツ装飾芸術調查において備え付けの家具について関 心を示しながら梁21)、確信を持てないでいる。

しかし、ペレの考えを知ることによって、ジャンヌレは変節する。

「やはり動かせる家具など考えないように用心しなくてはなり ません。しかしジュルダンはお高くとまって、人間のことなど 考えてもいません。尻や膝には具合が悪いのです。芸術品とし て楽しんでいるのです。快適さはどこへやら。フランシス・ジ ユルダンの理論はルイ 16 世の肘掛け椅子、あるいはトリアノ ンやコンピエーニュの帝国主義への媚びへつらいです。」注22) ペレ自身も住宅作品で家具を手がけているが、ジャンヌレに宛て たペレの書簡が失われているために、ペレの「家具」に対する少な くとも当時の考え方を知ることはできない。ジャンヌレとの書簡の 変遷から、ペレはおそらくジュルダンの「動かせない家具」に肯定 的であったと推測される。そしてジャンヌレは、かつてラ・ショー =ド=フォンの顧客のために買い求めた様式的な家具を否定し、ジ ユルダンに触発された「動かせない家具」の考え方に確信を得る。 それはペレの考えの盲目的な受容ではなく、ドイツの装飾芸術に見 られたような空間の「統一性」に対するジャンヌレの志向も作用し ていると考えられる。

\section{0 年代における「装備」の探求}

しかしそれにしても、ジャンヌレにとって、工業製品化を意識し たジュルダンの家具は、家具のための家具である。この批判が、1920 年代の「装備」の概念を準備することになる。

\section{3-1「棚」}

ジャンヌレがル・コルビュジエとして「家具」について直接論究 寸るのは、『今日の装飾芸術』(1925) においてである。ル・コルビ ュジェは、「家具」を次のように分類する。

「手足のようなオブジェは、定型の必要に応じた、定型としての オブジェである。腰かけるための椅子、仕事をするための机、照明 寸るための照明、文字を書くためのタイプライター(そうなのだ!)、 分類保存のための棚。」注 23 )

ル・コルビュジエによれば、本来の「装飾芸術」の最小単位は「手 足としてのオブジェ objets-membres」、すなわち「家具」である。 「手足としてのオブジェ」はしかし、生活における多種多様な要求 を臨機応変、変幻自在に解決するものではない。ル・コルビュジェ によれば、人間が必要とするものには、少数の「定型 type」に分類 されるはずである。なぜなら、我々人間は同じ「身体」を保有して いるからである。日常において反復される恒常的で最も原初的な身 
体動作を反映したものが、「椅子」「机」「照明」「タイプライター」 「棚」である。したがって、身体の延長ではない壁紙や䋐毯やカー テンあるいは暖房器機などの所謂室内の「装飾芸術」は、身体の感 覚に適うものではないために、この範疇には入っていない。

身体動作に恒常性があるならば、「手足としてのオブジェ」は標準 化、そして量産化が可能になるはずである。ドミノ型住宅の特許登 録（1914）に係る建設技術の研究をはじめとして、1920 年代にシ ロトアン型住居の量産住宅の研究を始めて以来、ル・コルビュジエ には家具の量産化も念頭にある。1925 年にパリ近代装飾芸術・工業 美術国際博覧会に出品したレスプリ・ヌーヴォー館（1925）のプロ トタイプの提案において (Fig. 1)、ル・コルビュジエは「家具」の 問題に取り組み、なかでも「棚 casier」を研究の主題に据える。『近 代建築名鑑』（1926）のにおけるレスプリ・ヌーヴオー館の「装飾 芸術 art decoratif」の解説のなかで、ル・コルビュジエは次のよう に述べる。

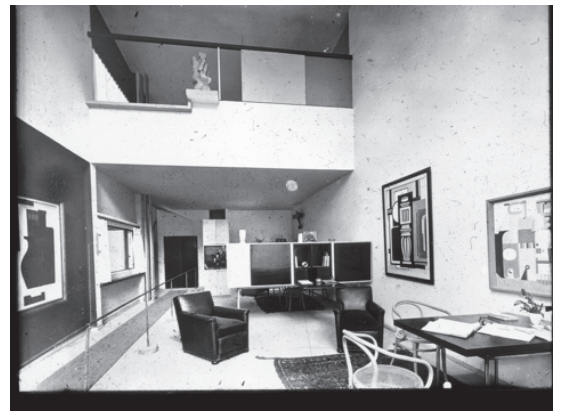

Fig.1 Interior of L’Esprit Nouveau (1925) 注

「家具はここでは、すでに完成している建築を尤もらしくする ようなものではない。家具が建築をつくる。賢者や貧者の粗末 な棚も、豪奢に取り巻かれることを願う人びとの最も高価で豪 華な棚になり得る。そこで私たちは装飾芸術の決定的な変革の 概要を示した。すなわち棚である。手で自由に操作でき、必要 であると感じられる正確な場所に適合し、規格の問題を解決す るべく応用された工業の発展によって実現された完璧な機能を もつ棚である。」注 25$)$

レスプリ・ヌーヴォー館におけるル・コルビュジエのねらいは、 ジュルダンのように建築躯体とそれと一体化する家具の形式的な統 一をめざしたものではなく、正確な場所におくことによる自由な操 作」を可能にする「家具」を規格化することである。その考え方を 明快に表現するには机や椅子よりも「棚」が有効である、とル・コ ルビュジエは考える。

『近代建築名鑑』(1926) におけるレスプリ・ヌーヴォー館の「装 飾芸術」の解説は、「棚」にはじまり、「椅子」、「照明」、「机」、「彫 刻・絵画作品」、「多彩色 [壁面塗装]」「自然採光」へと言及が続い ていく注26)。「多彩色」はともかく、「自然採光」は古典的な室内装 飾の主題に当てはまらない。「装飾芸術」と「建築」の境界は曖昧で ある注27)

そしてル・コルビュジエは、『全集』第 1 巻（1929）のレスプリ・ ヌーヴォー館の解説において「装備 équipement」という言葉を用 いるようになる。「装備」という言葉の選択は、もちろん「装飾芸術」 という古典的概念に対する対案であるが、ル・コルビュジエはここ
でも問題を「棚」に限定する。

「装備とは、家庭生活に必要な各種要因を分類し、問題を解決 することである。無数の家具、いろいろな姿形をまとい、さま ざまな名をつけられたものに代って、標準の棚を壁に組込み、

壁に寄せ、住戸の中で毎日正確に使われる場に置き、目的に応 じて内部に装備する。」注28

すなわち、ル・コルビュジエにおいて「棚」と建築躯体の一体化 の問題は、両者の素材や色彩の統一ではなく、壁との形式的な関係 の強弱によって規定される。ラ・ショー＝ド＝フォンにおいて実践 を積んできたような書斎（ディティス八イム邸の書斎（1915）、シ ユウォブ住宅の貴賓室（1916）、ルヴァイアン邸の書斎（1923）な ど）の作り付け、すなわち壁に「組み込むこと」に加えて、壁に「寄 せること」、そして壁から自立して「置くこと」ができる。「置くこ と」はまた、それ自体が空間を仕切る壁になるような配置を含んで いる。言説において建築躯体と関係づけられる「棚」の方法論は、 以前よりはるかに多様化していく。

\section{3-2 「法」}

1927 年にシャルロット・ペリアンが家具のデザイナーとしてル・ コルビュジエのアトリエに入所して以降、装備」の探求は深まりを 増していく。ラ・ロッシュ邸（1923）のギャラリーの改修（1928） を前後して、「棚」を壁に備えるだけではなく、ペリアンと共同で量 産を目指した、自立した鋼管製の「棚」、机」、椅子」の開発を行い、 1929 年にサロン・ドートンヌに出品する（Fig. 2)。

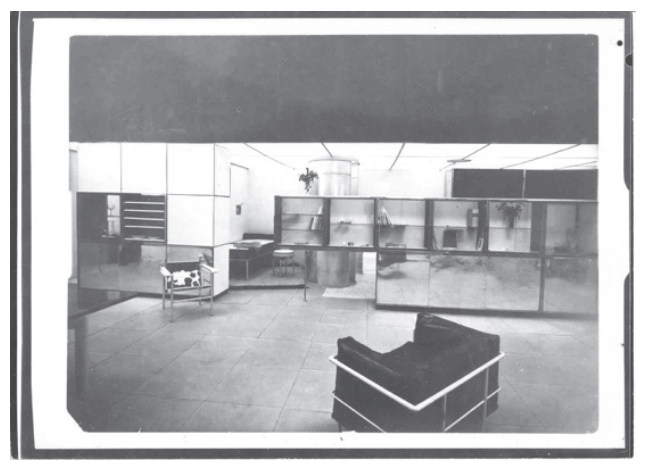

Fig.2 Interior of Le Salon d'Automne (1929) 注29)

ル・コルビュジエは同時期に敢行した南アメリカ初訪問と連続講 義録、『プレシジョン』（1930）において、「家具」を机、椅子、棚 に分類し、身体動作と日常生活における恒常性を前提としていると ころは、1925 年以来から変わっていない注30)。

ル・コルビュジエは講演において、さらに続けて次のように言う。

「椅子と机を別にすれば、家具は本当のところ棚だけなのです。 ところがほとんどの場合、これらの棚は寸法が正確ではなく、 用途は不明確。私はここで無駄を排除したい。この的を打破し、 家具が本当に何の役に立っているのかを明らかにしたいのです。 木材及び金属の新しい工業をもってすれば、驚嘆すべき機能と、 大体ではなく明確な寸法の棚をつくることができると確信した のです。」注31)

「家具」の問題が「棚」に集約されるにしても、定型の探求は、 具体的な「寸法 dimension」という形式を取っている。それはル・ コルビュジエが明言するように、ペリアンとの協働による人体の動 
作から導き出されたものであり 注32)、後の「モデュロール Modulor」 （1948）の寸法体系の作成に結実する。

それはまるで、動かない家具が組み込まれた建築作品の室内空間 というよりも、「人間的尺度 échelle humain」だけが規準となる移 動機関の室内空間のようである。たしかに「人間的尺度」という問 題設定においては、建築/家具という二稿対立そのものが無効であ る。だれも飛行機の客席で「家具」という発想をすることはない。 利用者の意識は「快適な」時間に向けられ、それに奉仕する道具に ついては、「人間的尺度にぴったりして」いればいるほど、それを意 識することがない注33)。

しかしながら、旅のひとときとは異なって、住宅の日常生活にお いては、様々な動作の様態が問題になる。ル・コルビュジエは、と りわけ椅子における動作の型について詳細な研究を行っているよう に (Fig. 3)、「装備」の問題は、「寸法」という主題においては、「棚」 だけではなく「椅子」や「机」も含まれるようになる。

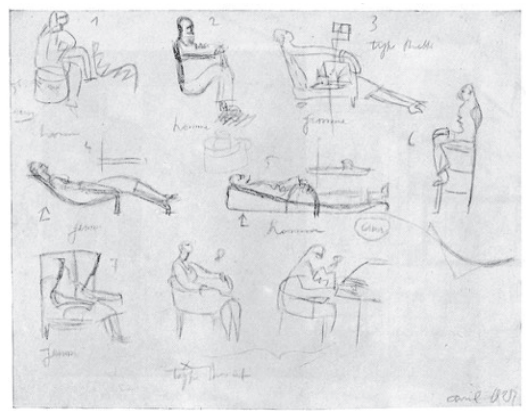

Fig.3 Studies on the different way of sitting (1927) ${ }^{\text {注 } 34}$

あるいは、「装備」の問題は、その出発点として分類した「家具」 の問題に留まらないかも知れない。ル・コルビュジエはこの講演の 最後に、「家具」の改革を女性の衣服に喻えて説明する。

「現代の女性は髪を切ってしまいました。我々の視線は女性た ちの脚の形をとらえました。もうコルセットは存在しません。

「礼儀作法」は地に墜ちました。礼儀作法は宮廷で生まれたも のでした。一部の人だけが座る権利を持ち、そして、それも、 坐り方まで決まっていたのです。

[中略]

そして、特に我々は今もっといい具合に座っています！

住宅は家具がなく空っぽです。

空間と光とが満ちあふれています。

動きも、活動も迅速です。

そして、休息の時、ゆったりとしている時に、自分の家で、何 かを考えることができる歓びを持つことができるのではないで しょうか。

これが本質です。何かを考えるということが。」注35) ル・コルビュジエは慣習を捨てた衣服に映えるのは、「考えること」 の自由に裏打ちされた身体の美しさである。身体を束縛する「家具」 は排除されなければならない。

「棚」はその方法論である注 36 )。なぜなら、目的が室内空間におけ る自由度であるならば、すべての「家具」は「棚」＝衣服のように (取り替え可能であるかどうかは別にして)「いい具合に」身体を包 むものでなければならないからである。「装備すること」と「身に着
けること」は、「寸法」の探求において接近し、「棚」という問題へ の限定を解除していく。

\section{0 年代前半における「装備」:「衛生」}

1920 年代後半からの一連の「装備」の研究は、ペリアンが実践 的な役割を担っているが、ペリアンは家具だけではなく、建設事業 において衛生設備も担当している（代表的なものは、チャーチ邸の 改築 (1929) やパリのナンジェセール＝エ＝コリ通り 24 番地のル • コルビュジエのアパルトマン（1933）など）。もちろん空間の「装 備」が「家具」の問題を出発点にしていたとしても、日常生活にお ける身体の動作を問題にするかぎり、そこには坐ることだけではな く、調理、摂食、排泄、掃除洗濯、入浴、就寝など、衛生器機に関 わる基本的な動作も含まれるはずである。しかし、ル・コルビュジ エが 1928 年に創設した CIAM（近代建築国際会議）においてはじ めから近代衛生学は主題の一つであったにもかかわらず注37、ル・ コルビュジエは所謂水まわりの衛生器機の問題について、「装備」と の関連で主題的に述べていない。ル・コルビュジエは自らのアパル トマンとアトリエ（1933）の設備にしてもペリアンに委任し、ル・ コルビュジエは衛生器機の配置について、詳細な指示やその根拠を ペリアンに説明することはない注38)。ル・コルビュジェ自身は、ア パルトマンの室内の「装備」を「新しい時代の感性」と呼応してい るとしか述べていないのである注39）

直接的には、戦後復興を見越した建築と都市問題の技術集団であ る ASCORAL (建築刷新ための建設者協会)の設立を前後して、『人 間の家』（1942）において、唯一、共著者ピエールフウが衛生設備 の問題を取り上げ、集合住宅における「装備」について述べている。

「[来るべき時代の集合住宅の］家庭用の整備には、浴室あるい はシャワー、洗面所、台所、それも人工換気が付いているが、明 らかに、優良な製品である。にもかかわらず、どこか大量生産 品、それも大量の、かなり大量生産品といった感じがする。素 材の質といい、形の輪郭といい、設計の精密さといい、どこか 自動車の車体か飛行機の胴体の「仕上げ」を思わせる。大きな 仕切りパネルが、ちょうど良い高さで、重なりあう棚になって いて、そこには個々のオブジェが都合良く自然に収納されてい

る。しかしながら、この実に注意の行き届いた装飾には、いかめ しさや、潤いのなさは少しもない。」注40)

たしかに、移動機関の室内に喻えられるその「装飾」は「装備」 そのものであるが、それは 1920 年代にル・コルビュジエが述べて きたことの繰り返しに過ぎない。しかし「装備」の主題は、「棚」だ けではなく、水を処理する衛生設備や空気を循環される換気設備も 含まれている。「装備」は「棚」の焦点化ではおさまらない拡がりを 見せている。

1937 年にル・コルビュジエのアトリエを辞していたペリアンは、 ふたたびマルセイユのユニテ・ダビタシオン（1952）の建設事業に おいて台所を担当するようにル・コルビュジエから依頼される。そ れはペリアンの「女性的感性」に託したからである注41)。台所など 水を処理する装備は、エスプリ・ヌーヴォー館 (1925) の解説以来、 ル・コルビュジエには理論化できない領域と考えていたと思われる。 あるいは、衛生設備は「棚」=「衣服」のようにはなり得ないのか も知れない。 
ル・コルビュジエは『建築の学生たちへの談話』(1943) のなか

で、再び女性の衣服に喻えて建築の装飾の問題を論じている。

「女性は、もうすでに、先を行っていたのです。仕立てや流行 は大胆で、感性的で、表現的です。1942 年の若い娘たちを見た まえ、その髪の健康的で楽観的なことを。彼女らは、頭に黄金 や黒檀をいただいている。ルイ十四世やルネサンスのころは、 青年諸君、君たちが、こうした髪をしていて、天使のように輝き、 マルスのように強く、アポロのように美しかったのです。娘た ちが君たちに王手を打ったのです!ところが、衣服の形は最も 不適合な時代にあり、さらにその上、生命のしるしである色彩 をも放棄しています。1910 年以来、私は石灰汁がもつ活力を与 え純化させる力を信じてきました。仕事を通じて、その白色の歓 びの輝きを示すようにするには、それを取り囲んで色彩のざわ めきが必要と悟りました。鉄筋コンクリートのなかに「自由な 面」（壁の束縛から開放された面）の萌芽を見た私は、建築に色 彩を適用することを思いついたのです・・・」注42)

第二次世界大戦中という時代は状況も影響していると思われるが、 ル・コルビュジエがここで自由な身体のために説明しているものは、

「棚」ではなく「色彩」である。そして「色彩」は、構造壁であれ間 仕切り壁であれ、概念的には床面から天井面までを覆う面的な「壁」 である。「棚」もまた「壁」になり得るのであれば、「色彩」は「装 備」の範疇である。したがって、ル・コルビュジエによれば、あく までオブジェとして自立する衛生器機は、「建築ではない」注43)。

\section{5 第二次世界大戦後の「装備」:環境装置として}

「装備」の問題について、マルセイユのユニテ・ダビタシオン (1952) の構想を前後して、ル・コルビュジエは再び多くを語るようになる。 1943 年にル・コルビュジエが創設した建築刷新のための建設者協会 （ASCORAL）の作業部会の一つとして「装備」が設置される。し かし、文書としては「居住の面に関し、人間に最も好適な環境を与 え、その使用者に、毎日の生理的、心理的、物質的要求の満足を与え てくれるような装備を決定すること」注44) とのみ記載され、具体的 な研究内容は明らかではない。

実際に、ル・コルビュジエが「装備」について内容に言及してい るのは、独自の寸法体系の理論とその応用を論じた『モデュロール I』（1950）と『モデュロール II』（1955）である。1920 年代後半の 「装備」の概念における「寸法」の重要性はすでに指摘したが、『モ デュロール I』（1950）においても、寸法体系の適用による家具の自 由な操作という主題は変わらない注45)。しかしその一方で、建築躯 体との関係は、1920 年代よりむしろ単純化されている。『モデュロ ール II』（1955）における「空」の探求の履歴について、ル・コルビ ユジエは元の所員と次のような対話をしている。

元所員：「そうして、年とともに、ガラス壁が「部屋の第四番目 の壁」となりました。もはやす心゙てがガラスではなくなったの です。不透明な板が入っています。書棚がこれについています。 机がこれに寄りかかっています。・・空は家具の一部類に属す るようになります。それ自体が、内外において、建築化される のです。」

ル・コルビュジェ：「それだけではありません。インドでは、呼 吸という問題を取り上げ、内部の換気を問題にしているのです。
カラス壁の 2 つの機能を仕分けました。つまり、換気すること と採光することです。」注 46 )

「家具」の問題を純粋に寸法として論じるのであれば、とりわけ 「壁」との関係が問われるわけではない。1920年代の「棚」のよう に、三次元の空間のなかのオブジェとして自立し、場合によっては それ自体が間仕切り壁として空間を分ける仕掛けになってもよいは ずである。しかしル・コルビュジエは、ここではあくまで「壁」と の関係に執着する注47)。あるいはむしろ、ル・コルビュジエは「壁 ／空」の二元論、そして「壁／空／家具」を解体し、むしろ等価に 扱っていると考えるべきかもしれない。「装備」はもはや空間自立す るオブジェの可能性を放棄し、概念的には新しい「壁」の概念を構 成するようになる。

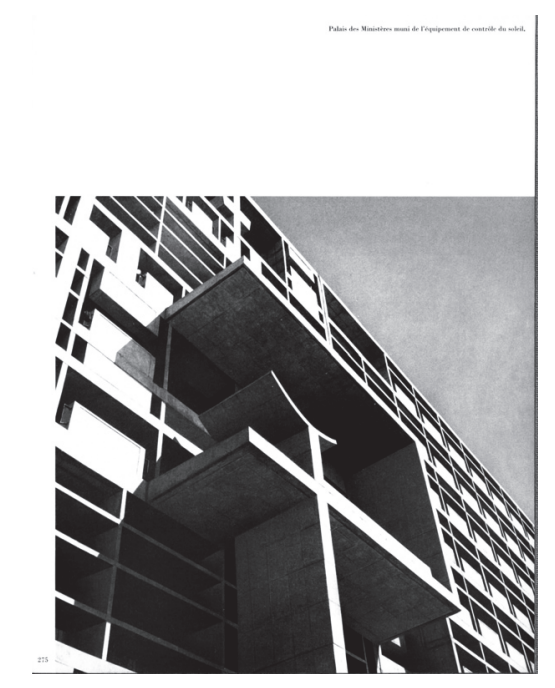

Fig.4 Government office building with the "equipment" of the sun control in the book of L'Atelier de la recherche patiente (1960) ${ }^{\text {注 } 48 \text { ) }}$

したがって、本来の壁に穿つ「空」さえも「装備」の問題に含ま れることになる。「空」は装飾芸術におけるシャンデリアに代わる自 然採光の装置なのである。しかも「空」は、換気も兼衫る。つまり 「空」は自然環境を制御する装置でもある。したがって、実質的に 最後の作品集となる『忍耐強き探求のアトリエ』(1960) において、 ル・コルビュジエはブリーズ・ソレイユの日除け装置でさえ、「装備」 として位置づけるようになる（Fig. 4）注49）。

\section{6 おわりに}

「家具」の問題から誕生し、室内空間の自然環境の制御の仕掛けに まで生成するル・コルビュジェの「装備」の概念の変容の過程は、 「壁」との関係性の変化として理解寸ることができる。「装備」は建 築躯体の「壁」から開放されて間仕切り壁のような別の「壁」とな る可能性を秘めながら、建築躯体の不動の「壁」へと回帰していく。 いわば「装備としての壁」である。

『モデュロール II』（1955）において、ル・コルビュジエはその ような新しい「壁」を「表面 surface」と呼んでいると考えられる。

「住みうる細胞的な空間を実現すること。ここにも精度が生理 的にも精神的にも快さを生み出すもととなる。この住みうる細 胞的空間はそれ自体が人間的な尺度の無数の組み合わせ可能な 表面を提供してくれる。」注50) 


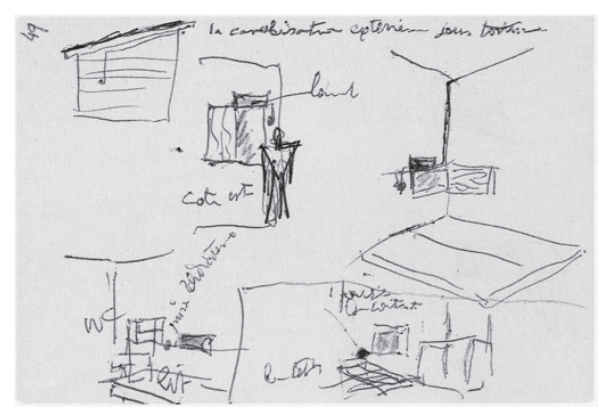

Fig. 5 Sketch of the ventilation, the water closet and the bedstead of Cabanon (1952.6.22) 注51

カプ=マルタンのル・コルビュジエの別荘、カバノン（1952）に ついてこの記述は、「装備」の到達点を要約している。カバノンは家 具、机、照明、壁画すべてが不動の作り付けであり、「天井」にも「装 備」が行き渡っている（Fig. 5)。椅子だけは動くが、基本的に内部 の居住空間において最後に残されて動くものは、人間の身体そのも のである。それを取り巻くものは一回的な自然を制御するための普 遍的な「装備としての壁」であり、衣服から建築躯体まで限りなく 境界は曖昧になっていく。したがって、その「壁」は不動でありな がら、それ自体では厚みのない「表面」として可変性を備えるという 両義性を有しているのである注52)

\section{参考文献}

1) Banham, R.: The Architecture of the Well-tempered Environment, Architectural Press, London, 1969

2) Barré-Despond, A., et al.: Francis Jourdain 1876-1958, Somogy Éditions, Paris, 2000 (in French)

3) Cinqualbre, O. and Migayrou, F., dir.: Le Corbusier, Measures of Man, Éditions du Centre Pompidou, Paris, 2015 (in French)

4) David-Will, H.: Guide of the Museum of Decorative Arts, Les Arts décoratifs, Paris, 2006 (in French)

5) Giedion, S.: Mechanization Takes Command, Oxford University Press, New York, 1949

6) Jeanneret, C-É.: Study on the Movement of Decorative Art in Germany, Haefeli et Cie, La Chaux-de-Fonds, 1912 (in French)

7) Jeanneret, C-É.: The Voyage to Germany, Sketchbook, Electa, Milano, Fondation Le Corbusier, Paris, 2000 (in French)

8) Jeanneret, C-É.: The Voyage to the East, Sketchbook, Electa, Milano, Fondation Le Corbusier, Paris, 2000 (in French)

9) Kries M., ed.: Le Corbusier, A Study of the Decorative Art Movement in Germany, Vitra Design Museum, Weil am Rhein, 2008

10) Le Corbusier: Archive of correspondences, Fondation Le Corbusier, 1907-1965 (in French)

11) Le Corbusier: Decorative Art of Today, G. Crès et Cie, Paris, 1925 (in French)

12) Le Corbusier: Almanac of Modern Architecture, Les Éditions G. Crès et Cie, Paris, 1926 (in French)

13) Le Corbusier: Complete Works, vols.8, Girsberger, Zürich, 1929-1970 (in French)

14) Le Corbusier: Precision on the Present State of Architecture and City Planning, G. Crès et Cie, Paris, 1930 (in French)

15) Le Corbusier: Talks with Students, Denoël, Paris, 1943 (in French)

16) Le Corbusier: Way of thinking of the City Planning (Manière de penser l'urbanisme), Éditions de L'Architecture d'Aujourd'hui, Paris, 1946 (in French)

17) Le Corbusier: The Modulor, Les Éditions de L'Architecture d'Aujourd'hui, 1950 (in French)

18) Le Corbusier: Modulor 2, Les Éditions de L'Architecture d'Aujourd'hui,
Paris, 1955 (in French)

19) Le Corbusier: Atelier of the Patient Reasearch, Les Éditions Vincent, Fréal \& Cie, Paris, 1960 (in French)

20) Le Corbusier: Le Corbusier Sketchbooks, Vols.4, Fondation Le Corbusier, Paris, The Architectural History Foundation, New York, Éditions Herscher / Dessain et Tolra, Paris, 1981, 1982 (in French)

21) Lucan, J., dir.: Le Corbusier an Encyclopaedia, Les Éditions du Centre Pompidou/CCI, Paris, 1987 (in French)

22) Morant, H. de and Gassiot-Talabot, G.: History of Decorative Arts, Hachette, 1970 (in French)

23) Mumford, E.: The CIAM Discourse on Urbanism, 1928-1960, The MIT Press, Cambridge, Massachusetts, 2000

24) Perriand, C.: A Life of Creation, Éditions Odile Jacob, Paris, 1998 (in French)

25) Pierrefeu, F. de and Le Corbusier: The Home of Man, Librairie Plon, Paris, 1942 (in French)

26) Rüegg, A.: Le Corbusier, Interior Furniture 1905-1965, Verlag Scheidegger \& Spiess , Zurich, 2012 (in French)

27) Samuel, S.: Le Corbusier in Detail, Architectural Press, Oxford, 2007

28) Troy, N.: Modernism and the Decorative Arts in France, Yale University Press, New Haven and London, 1991

29) Tory, N.: Modernism by Le Corbusier and his texts on the decorative art in France, Le Corbusier and Japan, Kajima Publishing, pp.61-84, 1999 (in Japanese)

30) Werth, L.: Modern Furniture, Les Atelirs Modernes, 1913 (in French)

注

*引用はすべて原文のまま。但し、［］笹者による補注。

注1）「装飾芸術 art décoratif」は室内を演出する家具、食器、壁紙、タペス トリー、家具、照明器機、場合によっては服飾なども含む包括的な概念で ある (cf., Henry de Morant et Gérald Gassiot-Talabot, Histoire des arts décoratifs : des origines à nos jours, éd. Hachette, 1970)。

注2）『機械化の文化史』（1949）を批判的に受け継いだレイナー・バン八ム、 『環境としての建築』（1969）などにおいても、建築的な環境の人工的制 御に重点を置いている。

注3) cf., Nancy Troy, Modernism and the Decorative Arts in France, Yale University Press, New Haven and London, 1991.

注4) 《 équipement »の「装備」という訳出は、ル・コルビュジェの Euvre complète (Girsberger, Zürich, 1929)の日本語版における吉阪隆正による。 所謂「設備」だけではなく、ル・コルビュジェの équipement の定義に寄 り添うために一語で表すことは困難であり、やや特異な訳出であるが、本 論文においても一律にそれに準じている。

注5) cf., Préface Hélène David-Will, Guide du musée des Arts décoratifs, Les Arts décoratifs, Paris, 2006, p.161.

注6) cf., Arthur Rüegg, Le Corbusier, Meubles Intérieurs 1905-1965, Verlag Scheidegger \& Spiess, Zurich, 2012.

注7）代表的な物としては、以下である。cf., Flora Samuel, Le Corbusier in Detail, Architectural Press, Oxford, 2007; Arthur Rüegg, op.cit.; Cloé Pitiot, "Le Corbusier, le mobilier corps et âme", sous la direction d'Olivier Cinqualbre et Frédéric Migayrou, Le Corbusier, mesures de l'homme, Éditions du Centre Pompidou, Paris, 2015, pp.85-89; Mateo Kries, "Le Corbusier in Germany", in Mateo Kries ed., Le Corbusier, $A$ Study of the Decorative Art Movement in Germany, Vitra Design Museum, Weil am Rhein, 2008, pp.8-95.

注8）本稿では、ル・コルビュジエの言説を一次資料としている。具体的な制 作の分析については、別稿に譲りたい。

注9) «... mais il manque aux Allemands, je l'ai souligné au débout de ce rapport, la tradition et leurs mains sont encore inhabiles. Les Français donc relevèrent à leur meubles des barbarismes qui leur parurent insupportables et la critique fut plutôt acerbe. Voici donc ce qui motive la décision du Comité de l'Exposition de 1912, d'interdire toute décoration d'ensemble et de ne viser que le meuble isolé, ...» (Charles-Édouard Jeanneret, Étude sur le mouvement d'art décoratif en Allemagne, Haefeli et Cie, La Chaux-de-Fonds, 1912, p.31) 
注10) cf., Nancy Troy, op.cit., pp.63-66.

注11） 1910 年のドイツの装飾芸術の調査において、ジャンヌレはとりわけへ レラウのドイツ工作連盟の工房における量産体制に関心を示している。cf., Ch.-E. Jeanneret Le Corbusier, Les Voyages d'Allemagne Carnets, Electa, Milano, Fondation Le Corbusier, Paris, 2000, Carnet 3, pp.52-64.

注12）実際、ジャンヌレは師ペレに宛てた手紙などにおいて、しばしばウィ ーン分離派やドイツ工作連盟についてその表面的技巧を見抜いて批判して いる。cf., AFLC, E2-12-23, lettre de Charles-Édouard Jeanneret à L'Eplattenier, 1908.2.26 ; AFLC, E1-11-112, lettre de Charles-Édouard Jeanneret à AUjuste Perret, 1914.7.1.

注13）室内空間としてのドイツ装飾芸術のジャンヌレの評価は、様式的統一 というよりも、むしろ様式を創造する制作者の思想的な統一性を論じるこ とになる後のル・コルビュジェを予感させる。cf., Le Corbusier, "le respect des œuvres d'art”, L'art décoratif d'aujourd'hui, G. Crès et Cie, Paris, 1925, pp.119-129.

注14) «Les Parisiens peuvent rester sceptiques quant au goût, à cause de l'incompatibilité des deux races qu'on sent s'accuser ici, où tout ce qui s'offre aux yeux est en quelque sorte l'expression de l'âme allemande ; mais ces Parisiens, s'ils n'admirent pas tous, sont du moins impressionnés par l'harmonie qui est indéniable. Depuis les rideaux, les étoffes, les meubles, les tapis, les lustres, les vaisselles, les bibelots, tout est né d'un même désir de réaliser enfin le rapport, la proportiqn, la convenance, l'apparenté. j'ai dit que c'était éminemment harmonieux; ... » (Charles-Édouard Jeanneret, Étude sur le mouvement d'art décoratif en Allemagne, op.cit., p.41)

注15) Arthur Rüegg, "Équipement, Les contributions de Le Corbusier à l'art d'habiter, 1912-1937: de la décoration intérieure à l'équipement", in Jaques Lucan dir., Le Corbusier une encyclopédie, Les Éditions du Centre Pompidou/CCI, Paris, 1987, pp.124-126.

注16) «Les croquis de Jourdain me laissent dans une grande perplexité. Il y a dix ans qu'on faisait çà en Allemagne, mais je sais que ce doit être ici tout autre chose. Cependant le meuble fixé au mur a quelque chose d'immeuble, inquiétant si l'on songe que l'on doit vivre avec ça des ans. " (AFLC, E1-11-86, lettre de Charles-Édouard Jeanneret à Auguste Perret, 1913.11.27)

注17) cf., Léon Werth, Meubles modernes, Les Atelirs Modernes, 1913.

注 18) cf., Arlette Barré-Despond, "Un homme moderne", in Francis Jourdain, un parcours moderne 1876-1958, Somogy Éditions, Paris, 2000, p.57.

注19) cf., Nancy Troy, op.cit., pp.137-140.

注20）cf., Arthur Rüegg, op.cit., pp.124-126.; ナンシー・トロイ、天野知香 訳、「ル・コルビュジェのモダニズムとフランスにおける装飾芸術をめ巡る 言説」、『ル・コルビュジエと日本』、鹿島出版会、1999、pp.66-70。

注 21 ) cf., Ch.-E. Jeanneret Le Corbusier, Les Voyages d'Allemagne Carnets, op.cit., pp.64-65.

注22) « ... : il faut prendre garde de ne point aussi considérer le meuble mobile comme un tout en soi ; on l'élève alors à un rang trop haut ; il n'est plus le serviteur de l'homme - de ses fesses et de ses coudes. Il joue le rôle d'un objet d'art et c'est alors que le confort s'en va. Les théories de Francis Jourdain sont un garde à-vous pour ceux qui adulent trop un fauteuil Louis XVI ou Empire vu à Trianon ou à Compiègne. " (AFLC, E1-11-88, lettre de Charles-Édouard Jeanneret à Auguste Perret, 1913.12.7)

注23) "Les objets-membres humains sont des objets-types, répondant à des besoins-types: chaises pour s'asseoir, table pour travailler, appareils pour éclairer, machines pour écrire (eh oui !), casiers pour classer. " (Le Corbusier, L'art décoratif d'aujourd'hui, op.cit., p.76) 注24) 出典 : ALFC, L2-13-40.

注25) «Le meuble ici ne vient pas ajouter son architecture possible à une architecture déjà arrêtée. Il fait architecture. L'humble casier du sage ou du pauvre peut devenir le casier le plus coûteux, le plus somptueux de celui qui désire s'entourer d'opulence. Nous avons esquissé par là une réforme décisive de l'art décoratif : Les casiers appropriés, qui mettent à disposition de la main, à l'endroit précis où le besoin s'en fait sentir, une fonction impeccable réalisée par le cheminement sûr de l'industrie appliquée à résoudre un problème standart. " (Le Corbusier, Almanach d'architecture moderne, Les Éditions G. Crès et Cie, Paris, 1926, p.145) 注26)『近代建築名鑑』（1926）において、ル・コルビュジェは衛生設備の問 題については、言及していない。

注27）エスプリ・ヌーヴォー館（1925）における「彫刻・絵画作品」は異色 である。なぜなら、「彫刻・絵画作品」という要素は、その他の装備の要素 と異なって、建築と一体化することなく設置の自由が保障されている。芸 術作品は「手足としてのオブジェ」には規定されない。cf., Le Corbusier, op.cit., p.146.

注28) “L'équipement, c'est, par l'analyse du problème, classer les divers éléments nécessaires à l'exploitation domestique. Remplaçant les innombrables meubles affublés aux formes et aux noms variés, des casiers standard sont incorporés aux murs ou appuyés au mur, disposés en chaque endroit de l'appartement où s'effectue une fonction quotidienne précise, équipés à l'intérieur suivant leur destination exacte. " (Le Corbusier et Pierre Jeanneret, Euvre complète 1910-1929, Girsberger, Zürich, 1929, p.100)この言説では、壁に「組み込むこと incorporer」と「寄せること appuyer 、「置くこと disposer」、「装備する こと équiper」の関係は文脈上明瞭ではないが、意図としては、「組み込む こと」と「寄せること」と「置くこと」を総括して「装備すること」意味 している。cf., Le Corbusier, Précision sur un état présent de l'architecture et de l'urbanisme, G. Crès et Cie, Paris, 1930, p.115.

注29) 出典: AFLC, L1-20-6

注30) cf., Le Corbusier, Précision sur un état présent de l'architecture et de l'urbanisme, op.cit., p.108.

注31) “Je vais affirmer qu'en plan dehors des sièges et des tables, les meubles ne sont à vrai dire que des casiers. Or la plupart du temps, ces casiers sont mal dimensionnés et d'une utilisation précaire ; je dénonce ici le gaspillage. Je vais pousser l'ennemi dans ses retranchements, chercher à quoi servent véritablement ces meubles. J'acquerrerai [acquerrai] la certitude qu'avec les industries nouvelles du bois et du métal, on peut construire des casiers précis d'un fonctionnement admirable, d'une dimension non approximative ... " (Le Corbusier, op.cit., p.111).

『全集』においても、ル・コルビュジェは同じことを繰り返し述べている。 cf., Le Corbusier et Pierre Jeanneret, Euvre complète 1910-1929, op.cit., p.157.

注32) cf., Le Corbusier, Précision sur un état présent de l'architecture et de l'urbanisme, op.cit., p.113.

注33)『全集』においては、新しい時代の住居に関して、ル・コルビュジェは 「装備」の問題を次のように言い換えている。

«On remarquera d'autre par que l'efficasité impeccable de ces objets a conduit à une économie de place extraordinaire, formidable, miraculeuse.

Et bien! Envisageons donc le logis où se développe la vie familiale. Je dis, en raccourci, ceci : il nous faut un bel espace pour vivre à la pleine lumière, dans la journée, pour que notre " animal " puisse ne pas se sentir en cage, qu'il puisse remuer, avoir de l'espace autour de lui, devant lui, etc... Et pour tout le reste, souvenons-nous des belles croisières faites sur les transatlantiques et des séjours relativement confortables faits dans les carlingues d'avion ou dans des wagon-restaurants, où l'espace est infiniment mesuré, mais très exactement mesuré à l'échelle humain. " (Le Corbusier et Pierre Jeanneret, Euvre complète 1929-1934, Girsberger, Zürich, 1934, p.113) 「また一方、その無比の効率的な品物は並外れ、すばらしく、驚くほ どに場所を取らぬように節約されている。それでは! 家庭生活の営まれ ている住まいをとり上げて見よう。概略を言えば、こうです。昼間は、光 のいっぱいある所で十分の広さがあって、我々「動物」が籠にとじこめら れたと感じず、周囲に動ける場所があり、広さがあり、等々ですね。その 他のことでは、大西洋航路の楽しい船旅を、あるいは飛行機の機内や列車 の食堂車での比較的安楽なひとときを思い出してもらえればおわかりでし よう。そこでは空間がはっきりと測定でき、それでいて人間的尺度にび 
ったりしているのです。」

実際、ル・コルビュジェの手帖では、数々の出張に際して、船室や飛行機内、

列車の客室などの「装備」が事細かに記載され、とくに第二次世界大戦後 に顕著である。cf., Le Corbusier, Le Corbusier Carnets 1 1914-1948, Fondation Le Corbusier, Paris, The Architectural History Foundation, New York, Éditions Herscher / Dessain et Tolra, Paris, 1981, pp.802-804, 1945.1.4.

注34) 出典: Le Corbusier et Pierre Jeanneret, Euvre complète 1910-1929, Girsberger, Zürich, 1929, p.157.

注35) «La femme moderne a coupé ses cheveux. Nos regards ont connu la forme de ses jambes. Le corset n'est plus. "L'étiquette " est tombée. L'étiquette était née à la cour. Certaines personnes seulement avaient droit à s'asseoir et cela, d'une certaine manière.

Et surtout nous voici en train d'être mieux assis !

Et la maison s'est vidée de ses meubles.

L'espace et la lumière abondent.

On circule, on agit rapidement.

Et peut-être aurons-nous plaisir à penser à quelque chose, en cette heure du repos, à cette heure de détente, chez nous ?

Voilà le fond du sac, penser à quelque chose." (Le Corbusier, Précision sur un état présent de l'architecture et de l'urbanisme, op.cit., p.121)

注36) ル・コルビュジェは、1929 年の南米での別の講演において、様々な個 人邸宅の建設事業において探求して 1926 年に定式化した「新しい建築の 5 つの要点」（ピロティ、屋上庭園、自由な平面、水平横長空、自由な立面） に加えて、住宅作品における「「棚」を備えて場所塞ぎな家具を排除した内 部 l'intérieur muni de " casiers " et débarrase de l'encombrement des meuble」を挙げている。cf., Le Corbusier, Précision sur un état présent de l'architecture et de l'urbanisme, op.cit., p.123.

注37) cf., Eric Mumford, The CIAM Discourse on Urbanism, 1928-1960, The MIT Press, Cambridge, Massachusetts, 2000, pp.12-14.

注38) cf., Charlotte Perriand, Une vie de création, Éditions Odile Jacob, Paris, 1998, p.55.

注 39) cf., AFLC, E2-4-219, lettre de Le Corbusier à Lucien Hervé, 1949.12.15.

注40) “Les aménagements domestiques, salle de bain ou de douche, sanitaires, cuisine, avec leur ventilation forcée, sortent, de toute évidence, de la bonne fabrique, et pourtant, ils sentent la série, la grande, la très grande série. Dans la qualité des matières, dans le galbe des formes, dans la précision des tracés, quelque chose rappelle le " fini " d'une carrosserie d'automobile ou d'un poste de fuselage. De larges panneaux de cloisons sont formées de casiers superposés, à bonne hauteur, où chaque objet trouve son logement aisé et naturel. Aucun parti pris d'austérité, cependant, ni de sécheresse, dans ce décor si net et si soigné. " (François de Pierrefeu et Le Corbusier, La maison des hommes, Librairie Plon, Paris, 1942, pp.56-58)

注41) cf., AFLC, E2-18-396, lettre de Le Corbusier à Charlotte Perriand, 1946.5.2.

注42) “Les femmes, déjà, ont pris les devants : couture et mode sont hardies, sensibles, expressives. Voyez ces jeunes filles de 1942 : leurs chevelures témoignent de santé et d'optimisme. Elles vont, casquées d'or ou d'ébène. Sous Louis XIV et la Renaissance, c'est vous, garçons, qui, avec ces cheveux-là, eussiez rayonné comme des archanges, été forts comme Mars, beaux comme Apollon. Les filles vous ont damé le pion! Or, nous sommes au point le plus inadapté de la forme vestimentaire, ayant d'ailleurs, ici, renoncé à la couleur qui est l'un des signes de la vie. Dès 1910, j'ai cru à la vertu tonifiante et purifiante du lait de chaux. La pratique m'a montré que, pour faire éclater la joie du blanc, il fallait l'entourer de la puissante rumeur des couleurs. Discernant dans le béton armé le germe du "plan-libre " (un plan libéré des entraves du mur), je fus conduit à polychromie architecturale, ... » (Le Corbusier, Entretien avec les étudiants des écoles d'architecture, Denoël, Paris, 1943, s.p.)

注43) cf., AFLC, R3-9-81, lettre de Le Corbusier à Christian Zervos,
1933.1.21.

注44) “Définir l'équipement du milieu le plus favorable à l'habitation, assurant à ses occupants la satisfaction de leurs besoins quotidiens physiologiques, matérials et psychologique. " (Le Corbusier, Manière de penser l'urbanisme, Éditions de L'Architecture d'Aujourd'hui, Paris, 1946, p.168)

注45) cf., “ À l'intérieur de la cote 3.66 S.b. les menuiserie s'installent à l'aise, tous objets étant à portée de mains et répondant aux positions assis ou debout. " (Le Corbusier, Le Modulor, Les Éditions de L'Architecture d'Aujourd'hui, 1950, p.155)「336-S.b.の寸法の室内では、 建具はうまく収まる。すべてのものが手に届く範囲にあり、立ったり坐った りした姿勢に応じている。」

注46) «Puis, au cours des années, le pan de verre devient « le quatrième mur de la chambre "; il n'est plus totalement en verre; certains panneaux sont opaques; des bibliothèques s'y accrochent; des tables s'y appuient; ... La fenêtre passe au rang du mobilier, elle peut être architecturée pour elle-même, dedans et dehors..."

« Ce n'est pas fini. Aux Indes, j'ai serré de près le problème de la respiration et par conséquent de la ventilation à l'intérieur des locaux. J'ai clasée les deux fonctions du pan de verre : ventiler et éclairer. » (Le Corbusier, Modulor 2, Les Éditions de L'Architecture d'Aujourd'hui, Paris, 1955, pp.193-194)

注47）ル・コルビュジエの「壁」への関心を示す明快な事例は、壁画の制作 である。1936 年のヴェズレーのバドヴィチ住宅への壁画制作に遡るが、 1948 年にスイス学生会館（1932）の読書室北側内壁に当初の「写真フレ スコ la fresque photographique」に替わって壁画を制作し、明確に「装備」 としている (cf., AFLC, C3-1-178, lettre de Le Corbusier à Pierre Baudouin, 1958.4.10)。

また、ル・コルビュジエは 1949 年頃からタペストリーの制作を精力的に 進めている。これもまた「壁」(「ノマド壁 muralnomade」) である。cf., Le Corbusier, Euvre complète 1946-1952, Girsberger, Zürich, 1953, p.237.

注48) 出典 : Le Corbusier, préface de Maurice Jardot, L'Atelier de la recherche patiente, Les Éditions Vincent, Fréal \& Cie, Paris, 1960, p. 275 .

注49）idid., p.275 の図版には、「太陽制御の装置を備えた総合庁舎 Palais des Minisitères muni de l'équipement de contrôle du soeil」と記載されてい る

注50) « réaliser le volume habitable alvéolaire. L'exactitude est encore ici une source de confort physique et intellectuel. Ce volume alvéolaire habitable propose de lui-même les surfaces à échelle humaine le plus variable. " (Le Corbusier, Modulor 2, Les Éditions de L'Architecture d'Aujourd'hui, Paris, 1955, p.255)

注51) 出典: Le Corbusier, Le Corbusier Carnets 2 1950-1954, Fondation Le Corbusier, Paris, The Architectural History Foundation, New York, Éditions Herscher / Dessain et Tolra, Paris, 1981, p.595.

注52）しかし、「装備」の室内の問題が自然環境との関係性に解消されるわけ ではない。ル・コルビュジェはチューリッヒの展示館「人間の家」（1967） の構想において、レスプリ・ヌーヴォー館（1925）やサロン・ドートンヌ （1929）にペリアンと協働で製作して出品した棚を今後の構想についても 実現していきたいという(AFLC, F1-3-316, Note à l'attention de l'Atelier, 1962.4.3)。実際、ル・コルビュジェはいろいろな「壁」のアイテムを保有 して放棄していない。

本稿は科学研究費助成事業基盤研究（C）（一般）課題番号 15K06399 の研究 成果の一部である。 


\title{
FORMATION OF THE NOTION ON “EQUIPMENT” BY LE CORBUSIER
}

\section{Shoichiro SENDAI*}

\author{
* Assoc. Prof., Graduate school of Engineering, Hiroshima Univ., Dr. Eng.
}

The turn of the "decorative art" in the 20th century has not yet discussed under the assumption of the negation of "decoration" by modernism in architecture. In this context, this paper aims to elucidate the formation of the notion on "equipment" by the Architect Le Corbusier (1887-1965), using his all kinds of books and his correspondences conserved in Le Corbusier Foundation in Paris.

Several periods were divided for this purpose: the question of "furniture" and the birth of the notion of “equipment" before 1920's, the theorization of "equipment" in 1920's, and its transformation after 1920's.

In the youth of Le Corbusier, under his real name Charles-Édouard Jeanneret, he made out the report of Study on the Movement of Decorative Art in Germany (1912) to investigate the production method by Deutscher Werkbund, while he was influenced by the French Architect Auguste Perret who pursued the possibility of the reinforced concrete and its classicism. In this condition, he could not settle his notion on "furniture": "mobile furniture" or "fixed furniture" in his viewpoint of human comfort.

It was the 1920's that Le Corbusier referred directly to the notion of "equipment" (Decorative Art of Today, 1925). His unique notion of "equipment" has come from the consideration about "furniture", in particularly, the question of "storage cabinet". According Le Corbusier, the "storage cabinet" is an "object-member" (object like the limbs), which has to fit with the body dimensions. Hence, his notion of "equipment" is extended to, not only desk and chair, but also "clothing". On the other hand, independent objects of body size, for example wallpaper, carpet, tapestry, or heating apparatus, what are called "decorative arts" do not belong to the category of "equipment".

After the 1920's, the notion of "equipment" proposed by Le Corbusier was more developed. He has been placing the treatment of wall "color" in the notion of "equipment" (Talks with Students, 1943). Moreover, he has been regarding even "window" which is opened out on the wall as "equipment". "Window" is a devise for the natural light instead of chandelier as the decorative art, and it is also a devise for the control of the natural environment (Modulor 2, 1955).

As a result, it can be seen that the Le Corbusier's notion on "equipment" has been spreading from "furniture" to the devise for the control of the natural environment. In conclusion, it is pointed out that such a formation of his notion is closed connection with his notion of "wall": In the 1920's, Le Corbusier proposed the tree types of installation: incorporate on the wall, lean against the wall and detach from the wall. However, he has come to incorporate all devises of "equipment" on the wall.

Therefore, the element of "mobile" is only the human body. All element of "fixed" is equipped with the wall. However this kind of "wall as equipment" have to have the function of "clothing" at the same time. Le Corbusier's "wall" is more ambiguous: although it is immovable, it is also flexible as devise for the control of the natural environment.

(2017 年 4 月 6 日原稿受理, 2017 年 5 月 23 日採用決定） 